Socialist Studies: the Journal of the Society for Socialist Studies 5(2) Fall 2009: 17-35

Copyright (C) 2009 The Author(s)

ARTICLE

\title{
Philosophy at the Service of History Marx and the Need for Critical Philosophy Today
}

\author{
JEFFREY NOONAN
}

Department of Philosophy, University of Windsor, Windsor, Ontario, Canada

\begin{abstract}
Marx is famous for apparently dismissing the practical role of philosophy. Yet, as accumulating empirical knowledge of growing life-crises proves, the simply availability of facts is insufficient to motivate struggles for fundamental change. So too manifest social crisis. The economic crisis which began in 2008 has indeed motivated social struggles, but nothing on the order of the revolutionary struggles Marx expected. Rather than make Marx irrelevant, however, the absence of global struggles for truly radical change make his early engagement with the role of philosophy more important than ever. This engagement suggests a conception of philosophy as a uniquely practical discipline distinguished from empirical science by its unique capacity to synthesise values from the facts of life. The article examines the development of this conception of philosophy in Marx's early work and concludes with the outlines for a new critical philosophy capable of generating a new set of universal values necessary to motivate anti-capitalist struggles today.

\section{Résumé}

Si Hegel a raison et que la philosophie émerge toujours dans un monde social dans lequel les contradictions se sont fossilisées, où le pouvoir d'unification semble avoir disparu, alors notre monde est un monde qui a besoin de la philosophie. L'automne 2008 a été témoin du début d'une crise économique qui promet d'être la pire de sa génération. La crise économique est liée à une crise politique de la démocratie sur le long terme (même si la crise n'est pas typiquement reconnue comme telle), caractérisée à travers le monde par un retrait de la régulation de l'activité économique par l'Etat et (sous le prétexte de la 'guerre contre le terrorisme') l'hyperrégulation des
\end{abstract}

\footnotetext{
Jeff Noonan is Associate Professor and Head of the Department of Philosophy, University of Windsor. His main research interests concern the foundation of solutions to the systematic life-crises caused by capitalism and universal ethical grounds of a fully democratic society. He is the author of Critical Humanism and the Politics of Difference (2003) and Democratic Society and Human Needs (2006). Noonan also serves on the Coordinating Committee of the Centre for Social Justice at the University of Windsor and is co-editor of the journal Studies in Social Justice.

Jeff Noonan est professeur associé et directeur du département de philosophie à l'université de Windsor. Ses recherches principales portent sur les fondements des réponses aux crises systémiques provoquées par le capitalisme et sur les bases universelles éthiques des sociétés véritablement démocratiques. Il est l'auteur de (en anglais) Critical Humanism and the Politics of Difference (2003) et Democratic Society and Human Needs (2006). Noonan est également membre du comité de coordination du centre pour la justice sociale de l'université de Windsor et corédacteur de la revue Studies in Social Justice.
} 
Socialist Studies: the Journal of the Society for Socialist Studies 5(2) Fall 2009: 17-35

vies publiques et privées des citoyens. Les crises économiques et politiques sont toutes deux enserrées dans une profonde crise environnementale provoquée par la croissance hypertrophiée de l'économie capitaliste dirigée par l'argent-comme-valeur. Si cette valeur est en crise parce qu'elle ne peut plus 'unifier' le monde social (elle est maintenant la cause et non pas la solution des problèmes fondamentaux de la vie humaine) alors la philosophie, si Hegel a raison, devrait être conviée en tant qu'unique pratique intellectuelle capable de générer une nouvelle synthèse sur la base des nouvelles valeurs (ou au moins une nouvelle articulation des anciennes valeurs).

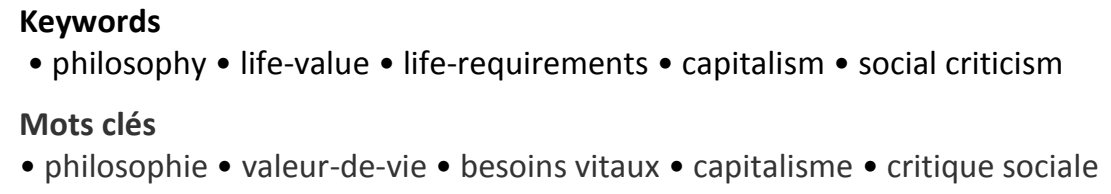

If Hegel is correct and philosophy always appears in a social world whose contradictions have become ossified, where it appears that the 'power of unification' has been lost, then ours is a world in need of philosophy (Hegel 1978, 12). Autumn 2008 witnessed the onset of an economic crisis that promises to be the worst in at least a generation. The economic crisis was related to a longer term political crisis of democracy (although this crisis is usually not named as such) characterised across the globe by a simultaneous withdrawal of state regulation of economic activity and (under the cover of the 'War on Terror') hyper-regulation of citizens' public and private lives. Both the economic and the political crisis are wrapped inside a deeper environmental crisis caused by the hypertrophied growth of the money-value steered capitalist economy. The longer-term threat to life and human life posed by the environmental crisis has recently been sidelined by politicians in full panic mode grasping for Keynesian mechanisms to restart the disrupted pattern of ever higher rates of commodity consumption, even though those rates of consumption, and the energy use they require, are at the root of the environmental crisis. The overall structure of the crisis, however, is neither environmental, nor economic, nor political, but normative. By 'normative' I mean that the crisis is generated by the steering value of contemporary liberaldemocratic-capitalist society. That steering value is the increase of money wealth understood not only as an economic 'necessity' but also the social condition of individual 'choice' and the essence of good human lives. If this value-system is in crisis because it can no longer 'unify' the social world then philosophy, if Hegel is correct, ought to be called forth to generate a new synthesis of values. 
Where, however, is philosophy? This question is not new but has been posed repeatedly in the history of philosophy. In terms most relevant for the present argument it was posed by Max Horkheimer in the early 1930s. Horkheimer was turning the Institute for Social Research in a new direction to enable it to understand the social and economic changes at the root of monopoly capitalism and mass culture. Like Horkheimer, I am interested in defending a conception of philosophy 'as a theoretical undertaking oriented to the general, the 'essential' ... capable of giving particular studies animating impulses'(Horkeimer 1993, 9). That which I take as 'essential' to philosophy is its unique capacity for synthesising values out of the facts of life. The Frankfurt School articulated some of the most sophisticated and important criticisms of twentieth century liberalcapitalist society, but conditions today are not the conditions of the 1930s or even the 1960s. Hence a new explanation of what it means to interpret philosophy as a value-synthesising discipline is required.

There is no doubt that many philosophers from many different philosophical traditions have engaged themselves with different dimensions of the normative problems underlying the global crisis. Yet, if we judge their efforts from the standpoint of civil society, the informal sphere of free association of which liberal and republican philosophers have been so enamoured over the past two decades, these efforts have been in vain. Philosophical interventions into the crisis have almost no public standing. Rare is the case where a philosopher appears on CNN, writes for the New York Times, is invited to non-academic conferences where concrete solutions to concrete problems are discussed, or even comes up in political conversation between citizens over a coffee or a beer. The public absence of philosophy is a sign that philosophy too faces a crisis, one whose timing could not be worse given the present world's need for philosophy. This crisis was first announced by Jean-Francois Lyotard more than two decades ago. 'Speculative or humanistic philosophy is forced to relinquish its legitimation duties, which explains why philosophy is facing a crisis wherever it persists in arrogating such functions and is reduced to the study of systems of logic or the history of ideas where it has been realistic enough to surrender them' (Lyotard 1984, 41).

There are exceptions, of course, the most important of which is perhaps Alain Badiou. Badiou directly confronts this crisis in Manifesto for Philosophy, but his response perhaps exemplifies rather than solves it (Badiou 1999). Badiou's ethical work, while it affirms a universal conception of the human good, rigidly distinguishes the good from our 'animal' embodied nature. His ethic of truths is divorced from all 
Socialist Studies: the Journal of the Society for Socialist Studies 5(2) Fall 2009: 17-35

connection to the fundamental requirements of human life. Truths are true just because people affirm them as true and persist in this affirmation against all opposition (Badiou 2001, 58; Badiou 2005, 202-208, 231-239, 331-343). Yet what is at stake in the present crisis of values is precisely the natural and social foundations of human life-support, the 'animal' precondition for commitment to truths whatever the content of those commitments might be. A philosophical response to this crisis that is worthy of the dignity of philosophy must articulate a new philosophical synthesis of the values that express humanity's intrinsic dependence on the natural world and our interdependence with others in the social world. It must do so because those are the values whose loss or suppression are at the root of the crisis of life-value today.

My argument will not explicate or defend the content of the new life-values that our world stands in need of today. I have defended what I take these values to be in many other places over the past several years (Noonan 2006; 2007; 2008a; 2008b). My focus here, rather, will be on philosophy itself, and in particular its being an essentially practical discipline uniquely structured to produce and defend a new value synthesis by a process of generalization of the 'facts of life.' Knowledge of these facts of life is supplied to philosophy, at least in part, by empirical disciplines. While this is a similar programmatic aim to that defended by Horkheimer, my historical touchstone lays behind the Frankfurt School in the work of Marx. Some, many Marxists included, will find this choice ironic given that Marx apparently rejected the practical nature of philosophy. Yet, Marx is the best historical platform from which to construct my argument. Marx was a philosopher that struggled repeatedly against philosophy. He was constantly tempted in his later work by what he took to be the methods of natural science, but was unable to free his work from the values first synthesised philosophically in his early work. Marx's body of work is famously huge, and I will not attempt a complete exegesis of even this thread of argument. Instead, I will focus for the most part on the period from 1843 to 1845 in which his self-conscious struggle within and against philosophy was most acute. Out of this struggle emerges a unique conception (or so I will argue) of the practical relevance of philosophy as a value synthesising discipline. In the second section I will generalise Marx's insights into a defence of philosophy today as the necessary condition for a new synthesis of life-values. These life-values must underlie, in some form, any possible solution to contemporary lifecrisis which is neither authoritarian nor regressive. 


\section{History, Philosophy, Values and the Future}

The Eleventh Thesis on Feuerbach is generally interpreted as Marx's final repudiation of philosophy in favour of empirical social criticism and revolutionary practice. His words are terse and his meaning apparently unambiguous: 'The philosophers have only interpreted the world in different ways. The point, however, is to change it' (Suchting 1979, 24). However, if we set this aphorism in the context of his reflections on the practice of philosophy that led up to this apparently ultimate break with the discipline, ambiguity does indeed emerge.

Marx's earliest systematic thoughts on the status of philosophy in relation to empirical disciplines like history are scattered throughout his early criticisms of Hegel's Philosophy of Right and in letters to Feuerbach and Arnold Ruge. When these thoughts are read in the political context in which Marx was working, it becomes clear, I believe, that Marx understood philosophy in two distinct ways. The first is as a discipline which synthesises values out of empirical knowledge of certain basic facts of life. The second is as an abstract discipline which holds itself above the fray of human struggles for a better life. In order to understand this difference, and the contemporary significance of the first conception, it is essential to keep in mind two elements of Marx's political context. First is the contradiction, remarked upon by all progressive German intellectuals of the time, between the economic and political 'backwardness' of Germany and its 'advanced' philosophical culture. Second is the Young Hegelian understanding of the function of philosophy.

It was a staple of German progressive politics in the early $1840 \mathrm{~s}$ that philosophy would have to play an outsized role in the emancipation of Germany from its backward social and political conditions (Kouvelakis 2003, 235). Since German industrial development lagged behind England, it could not look to a powerful working class to lead progressive struggles. Furthermore, since Germany had not undergone a classic 'bourgeois' revolution as had France, its national political consciousness was also underdeveloped. Hence intellectuals would have to play a more profound mediating role than in either England or France. In other words, young German radicals argued that the very social backwardness of Germany enabled German intellectuals to develop a richer understanding of human emancipation because their thinking was not dominated by the need to first construct and manage a liberal-capitalist society. German philosophers could prepare the future in theory, and had only to await the inevitable development of the social forces necessary to realize the idea. 
Socialist Studies: the Journal of the Society for Socialist Studies 5(2) Fall 2009: 17-35

'The only practically possible liberation of Germany,' Marx wrote, 'is the liberation that proceeds from the standpoint of the theory [Feuerbach's] which proclaims man to be the highest being for man'(Marx 1975a, 187).

As is evident, at this point Marx does not conceive philosophy as 'only' an interpretation of the world. He understands philosophy as the intellectual discipline that identifies and proclaims the universal value foundation for truly revolutionary political change. That universal value foundation is a materialist understanding of human nature, an understanding which, as we will see, emphasises both humanity's dependence on physical nature and interdependence with each other in social relationships (especially economic and political relationships). The German revolution will be the most radical precisely because it rests on a deeper value foundation than was possible in France and England, because French and English revolutionaries had to fight both for and against liberal values. These values obscured from their understanding the deepest contradictions between capitalism and human freedom. These contradictions themselves, Marx argued, stemmed from the alienation that capitalism imposes between the human collectivity and nature and between human individuals locked in zero-sum competitive social relationships.

Since there was no revolutionary bourgeoisie in Germany, philosophers were able to grasp in mind what capitalist social dynamics denied in material reality. The importance of this mediating role is what concerns me most. For Marx philosophy is framed but not determined by the past and present. Instead its systematic impulse towards universality pushes it beneath immediate contradictions in search of the ultimate foundations of human social life. These ultimate foundations, the most basic facts of life, then function as the material out of which philosophy can synthesise universal values and posit these as the normative foundation of a free social order to be constructed in the future.

It is this understanding of universal values as embedded in the fundamental facts of natural and social life that distinguishes Marx's conception of philosophy from his Young Hegelian contemporaries. Beneath the class identities of the groups contending for power and legitimacy lies the humanity of the combatants. It is only when philosophy understands this humanity that it can become properly radical. History, which Marx uses as a portmanteau term for all manner of empirical enquiries into the structure of human life, explicates the particular structure of the facts of life as they change across social space and time. Three general facts are crucial: our dependence on nature, our social need 
to produce what our lives require, and the general capability to do so as agents, or the fundamental form of human freedom this productive agency encodes. 'The task of history,' he writes, 'is to establish the truth of this world. The task of philosophy, which is at the service of history, is to unmask estrangement in its unholy forms' (Marx 1975a, 176). History establishes the truth of the given social world by comprehending the interaction between material forces and human struggles that have produced the different forms of human society. This is an essentially empirical task. In these early writings, however, Marx does not assume, as he later would, that the future can be known on the basis of understanding the laws of the present 'with the precision of a natural science' (Marx 1970, 21). Instead, the future is not an object of knowledge but a potential site for conscious self-creation. The possibility of self-creation, however, presupposes definite normative goals. Philosophy renders itself practical by synthesising these goals out of the raw material supplied by the empirical study of the 'unholy forms' of alienation. In the absence of philosophy all one has are certain facts of life. Since philosophy by its very nature concerns itself with the meaning of the facts of life, it is able to synthesise universal values out of what would remain, in the absence of a specifically philosophical intervention, mere facts. The process here is analogous to the action of a chemist creating a new compound. The raw materials for the compound are present in the elements that compose it, but the compound itself requires something not contained in the different molecular structures. It requires the creative thought of the chemist who can see how they can be fit together in ways that do not appear in nature. Likewise, meaning, the basic condition of there being values, is not present in the raw facts of life as facts of life, but must be supplied by a philosophical intervention.

Unmasking estrangement in its unholy forms cannot be an act of empirical criticism alone. For in unmasking estrangement, one is doing more than saying what human beings are, one is saying what human beings ought to become through a collective political project. If establishing the empirical truth of this world were sufficient to overcome it, then anytime one observes social problems one should also observe widespread movements to solve them. By including a statement of philosophy's task, however, Marx at least implies that universal values must be synthesised out of these facts as the necessary condition of motivating political change. If the truth of the world can be established by history, without that truth being in and of itself sufficient to motivate the process of political revolution, then philosophy, which deals with the ought-to-become, is an 
Socialist Studies: the Journal of the Society for Socialist Studies 5(2) Fall 2009: 17-35

irreducible practical contribution to the process of political change. For any empirical discipline ruling values (the values of self-estrangement) can only be given, historically contingent facts. The values that will organize the future, however, cannot be treated simply as facts, because the social reality in which they could circulate as facts does not yet exist. The values of the future exist as suppressed potentialities whose superior value cannot be proven by empirical arguments, since the data to support the empirical claims does not exist. Thus, only normative arguments rooted in, but not reducible to, facts about human nature and how it is affected by given social formations can play the required role. At the same time, philosophy does not preach from on high about mere aspirations or ideas. It is at the service of history. The values of the future that it defends are possibilities that history has disclosed, but which the present structure of society cannot realize. The values of the future are not mere oughts, (as Marx dismissed Kant's Categorical Imperative) but oughts-to-become which motivate because they respond to real life-crises felt in the present. The realizability of these values can plausibly be established by reference to what can be known from history about human potentiality (Marx 1976, 210-211).

A philosophy at the service of history does not thereby invent values ex nihilo. 'We do not confront the world dogmatically with a new principle... we develop for the world new principles out of the principles of this world' (Marx 1979a, 32). In other words, the values of the world that ought-to-become are produced by human historical activity, but can reach the fullness of their development, expression, and enjoyment only in a different social world. This social world cannot come to be without conscious effort, and conscious effort that would produce a new social world must be steered by universal, truly human values. Connecting past and future is human activity; separating present from future are the institutions of the given society. Marx is clear that these potentially ruling values cannot triumph simply as automatic results of the forces of history. 'It is not enough for thought to strive towards realization, reality itself must strive towards thought' (Marx 1975a, 183). This claim is far different from claiming, as Marx later would, that periods of crisis are the inevitable result of a contradiction between the forces and relations of production (Marx and Engels 1986, 39-40). That contradiction might generate social crisis, but revolution, to be successful, must also strive towards thought. In other words, there must be a conscious normative goal to motivate people to respond to the crisis in a revolutionary rather than a reformist way. 
Philosophy is thus a practical discipline for Marx to the extent that it clarifies the values according to which reality ought to strive.

This essential point is supported by contrasting it with a different conception of philosophy to which Marx was, and remained, hostile. This conception of philosophy dominated the Young Hegelian movement from which Marx was struggling to differentiate himself (Breckman 1999). The Young Hegelian understanding of philosophical practice was exemplified for Marx in the work of Bruno Bauer. For Bauer, the relationship between history and philosophy is the converse of that posited by Marx. Rather than philosophy being at the service of history, history is meaningful only in so far as it serves as the substance for philosophical interpretation. Moreover, the goal of this interpretation is not to derive from history the values that will lead radical political movements, but rather to disclose the unbridgeable chasm between philosophical ideals and historical development. As Bauer wrote, 'the critic participates neither in the sufferings nor the joys of society; he knows neither friendship nor love, neither hatred nor envy; he reigns in solitude, where now and then the laughter of the Olympian gods over the perversity of the world rings from his lips' (Marx 1979b, 36). For Bauer, therefore, philosophy is essentially contextless and timeless. Its role is not to 'strive towards reality' but to demonstrate that no matter how far human striving goes, it can never attain the Olympian heights of speculative criticism. Its relationship to history is therefore entirely negative. It can learn nothing from history, but nor, as a consequence, can it teach anyone anything of practical value. As Bauer says, the critic reigns in solitude, above the swirl of events and the mundane joys and sufferings of ordinary people. Bauer's perspective is the purity of the Beautiful Soul of Hegel's Phenomenology of Spirit who dares not act for fear of burdening his principles with the unpredictability of consequences (Hegel 1987, 383-409).

Marx, however, demands action, but not normatively blind action. Collective struggles must serve general yet definite values synthesised out of those aspects of the facts of life which are meaningful because they are requirements of human life and free human activity. What are the most salient facts? To uncover these it is necessary to examine in general Marx's understanding of how the relationships between human beings and nature and between human beings and each other become alienated under capitalist social relationships. Three facts are essential: Human beings cannot live apart from on-going interactions with the natural world. 'The life of the species, both in man and in animals, consists physically in the fact that man (like the animal) lives on organic nature' (Marx 1975b, 275). 
Socialist Studies: the Journal of the Society for Socialist Studies 5(2) Fall 2009: 17-35

As John Bellamy Foster demonstrates in exquisite textual detail, it is the primacy of this connection between humanity and the natural world that underlies Marx's entire critique of capitalism. He argues that 'alienation from the natural world is the fundamental form of human alienation'(Foster 2000,174). Second, human beings do not live ready to hand on what they find in nature but together in societies which cooperatively produce that which each and all require to live. 'Thus the social character is the general character of the whole movement: just as society itself produces man as man, so is society produced by him. Activity and enjoyment, both in their content and in their mode of existence, are social' (Marx 1979b, 298). Finally, and as a consequence of the first two points, human freedom is at first a fact of the productive nature of human beings. Freedom is not created in the first instance by political forms or legal structures, but is essentially the power of human beings to consciously produce their conditions of existence. This production has both a biological and a social dimension. Production both maintains human life and creates the meaningful forms through which human beings interpret their world and find their own purposes within it. As Marx says, 'the productive life is the life of the species. It is life-engendering life. The whole character of a species ... is contained in the character of its lifeactivity; and free, conscious activity is man's species character' (Marx 1979b, 276). These facts are transhistorical constants of human life. Yet, read philosophically, from the standpoint of why they matter to human life, they permit the synthesis of definite universal values that can then guide the development of the world that ought-to-become.

What explains the move from a mere description of general facts to the philosophical synthesis of the values they contain? This crucial move is what Horkheimer, for example, does not explain. The movement is generated by the way in which specific structures of a given society can contradict the general facts of human life. While some philosophers may object that contradictions can only hold between propositions, this view is overly narrow. Specific social structures can contradict the general facts of life when those specific structures prevent people from satisfying their liferequirements, even though the essential purpose of society is to enable people to satisfy those requirements. Take for example the most general fact of human life, its dependence on the natural system of life-support. Human labour transforms the natural world in order to provide the goods necessary to sustain life. In capitalism, by contrast, life becomes dependent upon labour and commodity markets; money becomes a condition of acquiring the goods that we need to live. People can therefore 
suffer harm, not because resources in general are lacking, but because people lack paid work and therefore the money required to purchase needed resources. In this way the specific structure of capitalist markets contradicts the general fact of the human need for certain resources to keep themselves alive. People are intelligent and can recognize this contradiction. When they do they construct normative arguments which maintain that it is wrong for social structures to impede access to that which they ought to provide: those life-requirements necessary to existence and a good life.

Marx initially seems to have planned a much more systematic synthesis between empirical science and philosophy. He hoped to create a genuinely philosophical science that would supersede the opposition between natural and human science. 'To assume one basis for life and one basis science is as a matter of course a lie' (Marx, 1975b, 303). Science presupposes life. The reproduction and meaningful social development of life presupposes on-going connection with the natural world in forms of productive relationship which prioritise the satisfaction of both natural and social life-requirements. The conscious nature of human productive relationships prove that human beings are not programmed machines but invent their own social conditions of life. From these three claims it follows that science, the principled understanding of the universe by conscious human beings who dwell within it, must ultimately be unified. This unity cannot be reductive, however, because reductive physicalism eliminates the human sources of wonder, imagination, and caring that motivate science in the first place. Instead, the unity, Marx suggests, must be synthetic and not reductive. The science of which Marx speculates here would be a complex explanation of how the capacities and values that steer human action emerge out of productive activity and how they are furthered or impeded by the particular steering values of a given productive system. All sound scientific inquiry must link back to the general conditions of life and what makes it better or worse. The new science would thus be a science in which normative goals are intrinsic, not as mere facts as an empirical sociologist would treat them, but as real values whose progressive development and realization the empirical understanding of the facts of life can help advance. In this synthesis, philosophy would be the crucial element since it is only the philosophical moment of the synthesis that can articulate the value dimension. Values are not mere artefacts found like minerals or plants, but but are consciously constructed. The conscious construction is in turn dependent upon the philosophical understanding of life's being meaningful. Only in 
Socialist Studies: the Journal of the Society for Socialist Studies 5(2) Fall 2009: 17-35

such a new science would the "chimerical" relationship between philosophy and natural science which Marx laments be superseded (Marx 1975b, 303).

Marx never completed this prospective synthesis of empirical science and philosophy. I will make some general suggestions in the next section about why such a synthesis ought to become a goal for scientists and philosophers alike today, and why philosophy alone can play the leading role in developing it. At this point, however, let us sum up this part by returning to the Eleventh Thesis and see whether it still reads like the complete rejection of philosophy it is generally taken to be. I believe that read in light of the preceding argument an initially unapparent ambiguity initially appears. Is Marx repudiating philosophy as such in the Eleventh Thesis, or is he only repudiating the timeless and disengaged philosophy preached by Bauer and others? The subsequent work of Marx does not resolve the ambiguity. As his work turns to the critique of political economy he often draws analogies between his work and the methods of the natural sciences (Marx 1986, 21). At the same time, the 'prescientific' normative ideas of alienation and truly human life-activity never disappear from his work, and are central to the Grundrisse and key arguments in Capital, especially his discussion of the labour process (Marx 1986, 173175). I have no intention here of solving the ambiguity or insisting, as Althusser did, on a fundamental 'epistemological break' in Marx's work, or in answering that charge, as others have already done (Althusser 1997, 4986; Meszaros 1970, 213-253). Instead I want to put the ambiguity to work in vindicating for the present the idea of philosophical practice central to Marx's own understanding of philosophy in 1843 and 1844.

When Marx says that philosophers have only interpreted the world, he is clearly rejecting the sort of philosophy practiced by Bruno Bauer. The rejection of philosophy as relentless negative critique of the present, undertaken from a purportedly timeless perspective claimed (but not defended) by the critic, does not entail, however, the rejection of a philosophy of the future whose relationship to the present is concretely situated criticism of the specific ways in which it impedes the free realization of human life-capabilities. That sort of philosophy does not simply interpret the world, but nor does it trust the world's transformation to inexorable historical forces or classes steered by their positional interests within a given social structure. Instead, philosophy as engaged critique of the present argues against ruling system values on the basis of deeper values synthesised by the philosophical understanding of the selfcreative processes at the foundation of historical change. By developing an 
account of universal values as emergent from the facts of human life, this situated, timely, and critical philosophy provides something that no other discipline can: an understanding of values as neither mere natural facts (about genetically regulated behaviour, for example) nor historical facts (functional rules necessary for social reproduction) nor laws imposed by transcendent divinity ('take it or leave it' divine commands), but as goals that emerge in historical development whose full realization depends upon the conscious, collective construction of a future society in which contemporary life-crises have been resolved.

Natural and social sciences would have a central role to play because they have immensely enriched our understanding of the natural and social frames within which human beings must act. Knowledge of these frames, in addition to being intrinsic epistemic goods, also contributes to a positive knowledge of human freedom by disclosing the space in which conscious human action and the values that steer it can make a difference to the future development of society. Knowledge of the frames of action does not, however, entail any conclusions about how we ought to act within them. The frames are the facts that await uptake in the new philosophical synthesis Marx proposed but did not develop. To actually develop that synthesis would require real collaboration and collective efforts, efforts which cannot be accomplished in a single paper. My focus in conclusion, therefore, will be on the role philosophy can play in such a synthesis, and why assuming that sort of role is key to the return of philosophy to the position of public prominence it ought to have.

\section{For a New Critical Public Philosophy}

The key to the solution of contemporary life-crises is the development of a new philosophical synthesis of foundational human values out of the facts of life in its natural and social dimensions. On this basis the universal structure of contemporary social problems can be coherently understood as a unified crisis of life-value across the natural and social dimensions of being alive. An essential moment of this synthesis is as rich an empirical understanding as it is possible to construct of the different concrete ways in which this unified crisis manifests itself. Biochemistry, atmospheric science, ecology, zoology, and oceanography are all essential to understanding what it means to say that there is a crisis of the natural conditions of life-support. Critical forms of empirical sociology, economics, history, and political science are essential to understanding the concrete effects of natural and social life-crisis on differently situated groups of 
Socialist Studies: the Journal of the Society for Socialist Studies 5(2) Fall 2009: 17-35

people. The 'lie' implicit in establishing different bases for life and science in effect means that the ultimate warrant of science, natural or social, is not to control nature in the service of a particular structure of ruling values and its attendant asymmetries of wealth, power, knowledge, and status, but to generate the practical knowledge necessary to improve lifeconditions for each and all who live. This goal, however, cannot be a goal generated by empirical science itself. Empirical science, in order to accumulate knowledge, must focus on its object and its object does not include 'value' in the normative sense required as the foundation of the solution to life crisis. Without philosophy the empirical disciplines risk 'sinking into empirical-technical minutiae,' with no value-ground, as Horkheimer worried (Horkheimer 1993, 14). Marx takes us some of the way to the goal in so far as his early struggles with and against philosophy disclose the method by which values may be synthesised from the facts of natural and social life. Yet Marx himself does not go far enough.

In his early struggles with and against philosophy Marx assumes a normative understanding of values as universal steering goals leading the struggle for a free and life-supportive society, but he never defines value as such. In his later political economic work value is defined in a one-sided way as exclusively materialised labour-time. That definition is inadequate to the deep normative arguments developed in his early work. These arguments were not essentially political economy, but focussed on the sorts of goals that political economy ought to serve. Yet Marx does at least imply the required understanding of value in so far as he implies that life is the fundamental condition of there being any value at all. This conclusion is implied in his claim that productive life is life-engendering life, and its converse, that there is a deep normative contradiction involved where, instead of engendering life, productive activity threatens or destroys it. Still, implying a conclusion and drawing a conclusion are logically distinct. Hence, in order to explicate the conception of value required by the new philosophical synthesis I am proposing, we need to go beyond Marx.

If we think of values in terms of the bases of motivation of an agent's (individual or collective) action, and keep in mind the obvious, that action requires life, then the satisfaction of the natural and social requirements of being alive as an agent are universal conditions of any action at all. From the perspective that understands life and the satisfaction of life's requirements as universal preconditions of activity, a value is 'that in the object which makes it an object of care and concern for a living subject.' This definition applies across the range of things that can have value and the different ways in which things can be valued. The 
reason why people care about food is because it has nutritional value, the reason why people care about education is because it has cognitive value (it is the only way in which the intellectual capabilities of the human brain can be developed); the reason why people care about politics is because it has social value in so far as its outcomes determine the legal frames within which active life must be led.

In general we can say that the overall goodness or badness of a society can be determined by reference to the degree to which its institutions and practices satisfy the natural and social life-requirements of its citizens being able to live as free, conscious agents whose concrete lifeexpressions contribute, via a virtuous circle, to the ability of other citizens to live as free, conscious agents. To the extent that these requirements are satisfied, citizens' lives increase in what McMurtry calls 'life-value.' Lifevalue is realized both in the satisfaction of natural and social liferequirements and the enjoyed expression of the human capabilities to sense and feel, think and act, in ways which do not unsustainably destroy the natural field of life-support or depend upon the exploitation and oppression of others for their expression and enjoyment (McMurtry 2008). Life-value is neither an abstraction nor a timeless ideal. It can always be determined by reference to the life-requirements that given societies satisfy and do not satisfy, and by the range and depth of the meaningful human capabilities their satisfaction enables and their deprivation disables.

A complete understanding of life-value requires a rich understanding of human life-requirements and human capabilities as well as the natural and social frames within which we must live. Empirical natural and social science thus play an indispensible role in understanding what these frames are and what their impact on existing and future human life is and will be. In order to create a society in which life-value is maximised for each and all, we need to understand the carrying capacity of the natural world, sustainable levels of resource extraction, how to create production processes which minimise toxic pollution, and how to produce clean energy at quantities sufficient for lives of maximum life-value but not beyond the carrying capacity of the natural life-support system. This synthesis also requires the contributions of empirical social science, and especially, as Marx argued, history. Those in positions of privilege need to hear, understand, and internalise the different experiences of exploitation and oppression of all the different subaltern groups. Concrete political strategies for life-grounded change cannot be inferred deductively from the general principle of life-value maximization, but can only be advanced 
Socialist Studies: the Journal of the Society for Socialist Studies 5(2) Fall 2009: 17-35

democratically in movements whose goals are emergent expressions of all subaltern groups experiences and ideas for change

In this way, the philosophically articulated idea of life-value forms the basis of a new synthesis of philosophy and empirical science. The unifying goal would be the full realization of life-value posited as the ought-to-become of the future. This ought-to-become is not a dogmatic and arbitrary stipulation of goal, but rather an empirically justified argument about the natural and social conditions for a life-coherent development of the human capabilities that make life worth living. Fundamental social change in the direction of more life-valuable forms of social organization is inconceivable in the absence of society-wide repudiation of the rule of money-value accumulation in favour of life-value maximization for each and all. Such a change in values must be empirically defensible. The required empirical defence can only be constructed with information concerning biological and social life-requirements and the capacity of natural and social worlds to satisfy them. Together, philosophy and empirical science united in the synthesis here proposed are capable of motivating change by disclosing the 'material irrationality' of the ruling value-system. By material irrationality, I mean that a set of ruling social values, if adhered to consistently over the long term, will undermine the life-support systems, natural or social, which even the ruling system values presuppose. In the contemporary world, faced with the environmental, economic, and political crises noted in the introduction, philosophy can best put itself at the service of history by consistently and systematically exposing and confronting people with the material irrationality of the prevailing value system.

As it was in Marx's time, so too in ours, the ruling value system continues to judge value in terms of money value, and affirms or repudiates collective and individual projects according to the likelihood of their returning profit to those that invest their time in them. As McMurtry argues, from within this system of value, 'nothing which is not an atomic money sum or priced commodity ... can register in this paradigm $=\mathrm{s}$ terms of reference, no shared life-good can exist for it' (McMurtry 2002, 134). Of course, this is not the only set of values at work. It is the socially dominant system, however, in so far as it is disseminated through the media, dominates culturally approved symbols of success, guides economic enterprises, and shapes government policy across the globe. Yet the growth of money value which this ruling value system demands is materially unsustainable. It is impossible, on a finite globe, for growing numbers of people to demand ever higher output and thus make ever 
rising energy demands without finally causing a global collapse of the lifesupport system of the natural world. What John Gray astutely remarks in relation to the looming oil crisis has general significance for any energy source; 'technology cannot repeal the laws of thermodynamics... When the energy costs of extracting oil exceed the energy thereby produced, no price can make the process profitable ... It is a consequence of the universal law of entropy' (Gray 2003, 67). Yet the ruling value system does in fact demand ever higher 'standards of living' as measured by market commodities consumed, and thus ever more energy to drive production. An empirically informed and life-grounded critical philosophical synthesis is the only intellectual basis which can expose the material irrationality of this system. Disclosing this material irrationality is, in turn, the precondition for a new opening toward a future that pursues the realization of different values by different means. This openness is not a contentless existential horizon, but a concrete opening for human action to change the world on the basis of new values generated from the empirical and rational demonstration of the material irrationality of the ruling value system. If philosophy remains institutionally marginalized and publically silenced then the world will lose its systematic capacity for self-criticism and conscious value transformation at just the point in history when it most needs philosophy's unique contribution.

These are not esoteric arguments. The need for a fundamentally different structure of ruling values is increasingly obvious because the evidence that speaks against the sustainability and justice of the present world order is more and more difficult to rationally deny. It is evidenced by the growing recognition across societies of the ecological unsustainability of capitalist economic practices, of the inexcusable waste of the lives of the two billion people who are forced to subsist on two dollars a day, by the moral insanity of armed conflicts that do nothing but set the stage for revenge and more killing, of the vacuity of consumer culture and the anaesthetizing effects of mass entertainment, of the mindless subservience demanded of most workers, and of the empty shell of democracy that ignores the considered demands and life-requirements of majorities. Far from being 'only' an interpretation, the philosophical practice of empirically informed social critique is the precondition of any intelligent and emancipatory social change that might emerge from these as yet disparate insights into the real structure of life-crisis today. 
Socialist Studies: the Journal of the Society for Socialist Studies 5(2) Fall 2009: 17-35

\section{References}

Althusser, Louis. 1977. For Marx. London: Verso.

Badiou, Alain. 1999. Manifesto for Philosophy. Albany: State University of New York Press

Badiou, Alain. 2001. Ethics. London: Verso.

Badiou, Alain. 2005. Being and Event. London: Continuum.

Breckman, Warren. 1999. Marx, the Young Hegelians and the Emergence of Radical Social Theory. Cambridge: Cambridge University Press.

Foster, John Bellamy. 2000. Marx's Ecology. New York: Monthly Review Press.

Gray, John. 2003. Al Qaeda and What it Means to be Modern. London: Faber and Faber.

Hegel, G.W.F. 1978. The Difference Between the Fichtean and Schellingian Conceptions of Philosophy. Atascadero: Ridgeview Publishing.

Hegel, G.W.F. 1987. The Phenomenology of Spirit. Oxford: Oxford University Press.

Horkheimer, Max 1993. "The Present Situation of Social Philosophy and the Tasks of an Institute for Social Research." In Between Philosophy and Social Science: Selected Early Writings. Cambridge: MIT Press.

Kouvelakis, Stathis. 2003. Philosophy and Revolution. London: Verso.

Lyotard, Jean Francois. 1984. The Postmodern Condition. Minneapolis: University of Minnesota Press.

Marx, Karl. 1970. A Contribution to the Critique of Political Economy. Moscow: Progress Publishers.

Marx, Karl. 1975a. "Contribution to the Critique of Hegel's Philosophy of Law. Introduction." Karl Marx and Friedrich Engels, Collected Works, Volume Three. New York: International Publishers.

Marx, Karl. 1975b. "Economic and Philosophical Manuscripts of 1844." In Karl Marx and Friedrich Engels, Collected Works, Volume Three. New York: International Publishers.

Marx, Karl. 1976. The German Ideology. Moscow: Progress Publishers..

Marx, Karl. 1979a. "Letter to Arnold Ruge." In The Letters of Karl Marx, ed. Saul K. Padover. Engelwood Cliffs: Prentice Hall.

Marx, Karl. 1979b. “Letter to Ludwig Feuerbach.” In The Letters of Karl Marx, ed. Saul K. Padover. Engelwood Cliffs: Prentice Hall.

Marx, Karl and Friedrich Engels. 1986. The Communist Manifesto. Moscow: Progress Publishers.

Marx, Karl. 1986. Capital, Volume 1. Moscow: Progress Publishers.

McMurtry, John. 2002. Value Wars. London: Pluto Press.

McMurtry, John. 2008. "What is Good, What is Bad: The Value of all Values Across Time, Places and Theories." In Philosophy Theme: Encyclopaedia of Life-Support Systems. Oxford: UNESCO and EOLSS Publishers. Available at www.eolss.net.

Meszaros, Istvan. 1970. Marx's Theory of Alienation. London: Merlin Press.

Noonan, Jeff. 2006. Democratic Society and Human Needs. Montréal: McGill-Queen’s University Press. 
Noonan, Jeff. 2007. "Social Conflict and the Life-Ground of Value." Philosophy Today 51, no. 4: 447-457.

Noonan, Jeff. 2008a. "Human Rights and Global Life-Support Systems." Philosophy and World Problems: Encyclopaedia of Life-Support Systems. Oxford: EOLSS Publishers and UNESCO. Available at www.eolss.net.

Noonan, Jeff. 2008b. “Normative Political Economy.” In Research Focus on Political Economy, ed. Walter Levin. Schenectady: Nova Science Publishers.

Suchting, Wal. 1979. "Marx's Theses on Feuerbach: A New Translation and Notes Towards a Commentary." In Issues in Marxist Philosophy. Volume Two: Materialism, eds. John Mepham and D.H. Ruben. Atlantic Highlands: Humanities Press. 